\title{
Filter-Press Cake as a Fertilizer
}

\author{
George Samuels and Pablo Landrau, Jr. ${ }^{1}$
}

\section{INTRODUCTION}

Every year the sugarcane mills of Puerto Rico produce large quantities of a byproduct ralled filter-press cake or filter-press mud. An arerage of 60 pounds of filter-press cake is produced for every ton of sugarcane milled. Assuming an output of 12,000,000 tons of millable cane per year, Puerto Rico has an annual production of about 360,000 tons of filter-press cake to utilize. This dark-brown to black organic material is usually dumped on or near the premises of the factory where it arcumulates in piles covering many acres. It is often used in fertilizing nearby sugarcane fields. The rates used are very high and applications up to 100 tons per acre are not rare.

Some filter-press cake has been used by home gardeners as a topdressing for lawns and gardens. The material has also found use in vegetable plantings and on pineapple plantations. However, no specific rate or method of application has so far governed its general use in farm practice.

Very limited information is available in the literature concerning the use of filter-press (ake in agriculture. Aside from work by Ramírez (5), ${ }^{2}$ Riollano (6), and Hernández-Medina, et al. (1-3), most of the reports that have appeared deal mainly with observed results rather than experimental proof.

Begimming in 1949, fertilizer experiments were ('arried out by the authors on some of the leading economic agricultural rrops of Puerto Rico in which results of the use of filter-press cake were compared with those obtained with inorganic commercial fertilizers. It is the object of this paper to report the results of these various experiments in which filter-press cake was used as a fertilizer material. The value of this material as a fertilizer will be discussed and practical recommendations will be made as to its use.

\section{PIIYSICAL, AND CIIEMICAL PROPERTIES OF FILTER-PRESS CAKE}

Filter-press cake consists principally of a mixture of sugarcane fibers, sucrose, coagulated colloids including cane wax, albumoids, and phosphates of lime, plus sand and soil. Most of the constituents come from the groundup sugarcane. The lime is added in the process of neutralizing and clarifying

1 Agronomist and Associate Agronomist, respectively, Agricultural Experiment Stat.ion, University of Puerto Rico, Río Piedras, P.R.

2 Numbers in parentheses refer to Literature Citerl, p. 213. 
the cane juice, and the sand and soil enter as foreign matter clinging to the cane.

Physically, filter-press cake is a soft, spongy, lightweight amorphous dark-brown to black material. It can readily absorb large quantities of moisture when dry. It generally contains from 55 to 70 percent of moisture on a wet basis when taken fresh from the factory. When allowed to airdry the moisture content averages about 15 percent. Its volume-weight is very low, being only 0.375 on a dry-weight basis, and about 0.57 at 65 percent moisture. Thus 1 ton of filter-press cake at 65-percent moisture (wet basis) would occupy about 56 cubic feet, or approximately 2 cubic yards.

Filter-press cake varies somewhat in chemical composition, depending upon such factors as the cane varieties being ground, the area where cane is grown, the climate, and mill performance. The range and mean values for the various chemical constituents of filter-press cake are given in table 1. These values represent many samples of filter-press cake taken from sugarcane mills from all of the cane-growing areas of Puerto Rico.

TABLE 1.-The chemical composition and physical properties of filter-press cake ${ }^{1}$

\begin{tabular}{|c|c|c|c|}
\hline \multirow{2}{*}{ Constituent } & \multirow{2}{*}{ Samples } & \multicolumn{2}{|c|}{ Composition on a dry-weight basis } \\
\hline & & Average & Range of values \\
\hline & Number & Percent & Percent \\
\hline Nitrogen $(\mathrm{N})$ & 43 & 2.19 & $1.07-3.13$ \\
\hline Phosphorus $\left(\mathrm{P}_{2} \mathrm{O}_{5}\right)$ & 43 & 2.77 & $1.34-6.30$ \\
\hline Potassium $\left(\mathrm{K}_{2} \mathrm{O}\right)$ & 41 & .44 & $.02-1.77$ \\
\hline Calcium $(\mathrm{CaO})$ & 42 & 3.05 & $.98-6.24$ \\
\hline Magnesium (MgO) & 2 & .49 & $.42-.58$ \\
\hline Manganese $\left(\mathrm{MnO}_{2}\right)$ & 6 & .17 & $.10-.24$ \\
\hline Iron $\left(\mathrm{Fe}_{2} \mathrm{O}_{3}\right)$ & 6 & 1.05 & $.26-4.71$ \\
\hline Boron $\left(\mathrm{B}_{2} \mathrm{O}_{3}\right)$ & 4 & .01 & $.00-0.02$ \\
\hline Organic matter & 1 & 39.5 & 一 \\
\hline Loss in ignition & 1 & 45.2 & - \\
\hline Sucrose & 4 & 3 & $2-4$ \\
\hline Moisture $^{2}\left(\right.$ fresh $^{3}$ & 18 & 61 & $56-69$ \\
\hline Moisture $^{2}$ (stored) ${ }^{4}$ & 23 & 15 & $9-47$ \\
\hline Volume-weight ${ }^{5}$ & 2 & .375 & $.372-.378$ \\
\hline
\end{tabular}

${ }^{1}$ Based on the analysis of samples taken by the authors, plus some given in literature $(3,5,6)$.

${ }^{2}$ Calculated on a wet basis.

${ }^{3}$ Fresh material taken from the Oliver and press filter at the mill.

${ }^{4}$ Material taken from the dump piles near the mills where it had been exposed to the weather.

${ }^{5}$ Calculated on a dry-weight basis and expressed in cubic centimeters per gram. 
Of the major plant nutrients (N-P-K), filter-press cake is highest in phosphorus as $\mathrm{P}_{2} \mathrm{O}_{5}$, nitrogen being generally a bit lower. The average values are 2.19 percent for $\mathrm{N}$ and 2.77 percent for $\mathrm{P}_{2} \mathrm{O}_{5}$, with fluctuations between 1.07 to 3.13 percent for $\mathrm{N}$ and between 1.34 to 6.30 percent for $\mathrm{P}_{2} \mathrm{O}_{5}$. The nitrogen occurs mainly as protein and in other complex forms rather than as the less complex ammonia or nitrate forms. However, conversion to these simpler forms proceeds very rapidly as the filter-press cake decomposes. Phosphorus is present in the form of complex organic combinations such as phospholipids and nucleoproteins. Some phosphorus is also present as calcium phosphates which were formed when the lime was added in the process of clarification. Usually most of the phosphorus is present in organic complexes which decompose readily to supply considerable available phosphorus for plant use.

The potassium content of filter-press cake is low. It averages 0.44 percent as $\mathrm{K}_{2} \mathrm{O}$ with a range from 0.02 to 1.77 percent-the higher figure being extremely rare. Inasmuch as potassium is not known to be fixed in the cane plant in any complex organic form, that present is extracted in the juice and by the water added in the milling process, and most of it is found in the molasses. The ash of molasses contains about 32 percent of $\mathrm{K}_{2} \mathrm{O}$ (5). The small quantity of potash present in the filter-press cake is in a soluble, very easily leached form.

The calcium content of filter-press cake is high and averages about 3 percent as $\mathrm{CaO}$. Most of the calcium is derived from the lime added when processing the sugarcane rather than from the plant itself.

Minor elements such as magnesium, manganese, iron, and boron are present in the filter-press cake in fair amounts - enough to make it a good source of minor elements for use by the plants. The iron content of filterpress cake averages about 1 percent. All of this iron may not be in readily available form, as some is found in the soil which forms part of the foreign matter, and part occurs as traces of metallic iron derived from the machinery used in the grinding of the cane.

\section{EXPERIMENTAL RESULTS}

In the experiments with filter-press cake as a fertilizer such crops as sugarcane, vegetables, tobacco, and root crops were utilized. The results obtained are reported under the individual crops.

\section{SUGARCANE}

The bulk of the filter-press cake used as fertilizer was applied to sugarcane. The results obtained from this material were not outstanding. As can be seen in table 2, cane yields were not appreciably increased where filter-press cake was used. It is to be remembered, however, that commercial 
TABLE 2.-Relative sugarcane yields for 4 soils receiving commercial cane fertitizers and filter-press cake

\begin{tabular}{|c|c|c|c|c|c|c|c|}
\hline \multirow{3}{*}{ Soil } & \multicolumn{4}{|c|}{ Fertilizer treatment, per acre, of - } & \multicolumn{3}{|c|}{$\underset{\text { acre }}{\text { Relative sugarcane yields per }}$} \\
\hline & \multicolumn{3}{|c|}{$\begin{array}{l}\text { Commercial inorganic } \\
\text { fertilizer as- }\end{array}$} & \multirow{2}{*}{$\begin{array}{l}\text { Filtex-press } \\
\text { cake } \mathrm{e}^{1}\end{array}$} & \multirow{2}{*}{$\begin{array}{c}\text { Tons of } \\
\text { cane }\end{array}$} & \multirow{2}{*}{ Sucrose } & \multirow{2}{*}{$\begin{array}{l}\text { Available } \\
96^{\circ} \text { sugar }\end{array}$} \\
\hline & $\mathrm{N}$ & $\mathrm{P}_{2} \mathrm{O}_{5}$ & $\mathrm{~K}_{2} \mathrm{O}$ & & & & \\
\hline \multirow{3}{*}{$\begin{array}{l}\text { Santa Isabel silty clay } \\
\quad \text { (irrigated) }{ }^{2}\end{array}$} & Pounds & Pounds & Pounds & Tons & Percent & Percent & Percent \\
\hline & 176 & 16 & 40 & 0 & 100 & 100 & 100 \\
\hline & 176 & 16 & 40 & 10 & 84 & 108 & 92 \\
\hline \multirow{5}{*}{$\begin{array}{l}\text { Santa Isabel silty clay } \\
\text { (unirrigated) }^{3}\end{array}$} & 250 & 0 & 300 & 0 & 100 & 100 & 100 \\
\hline & 250 & 0 & 300 & 20 & 94 & 102 & 96 \\
\hline & 0 & 0 & 0 & 20 & 97 & 96 & 93 \\
\hline & 0 & 0 & 0 & 40 & 93 & 95 & 87 \\
\hline & 0 & 0 & 0 & 60 & 82 & 97 & 80 \\
\hline \multirow[t]{2}{*}{ Coto elay ${ }^{4}$} & 250 & 300 & 300 & 0 & 100 & 100 & 100 \\
\hline & 250 & 300 & 300 & 10 & 103 & 100 & 104 \\
\hline \multirow[t]{2}{*}{ Lares clay 6} & 300 & 300 & 300 & 0 & 100 & $100^{\circ}$ & 100 \\
\hline & 300 & 300 & 300 & 20 & 112 & 101 & 111 \\
\hline \multirow[t]{2}{*}{ Vía silty clay ${ }^{6}$} & 300 & 300 & 300 & 0 & 100 & 100 & 100 \\
\hline & 300 & 300 & 300 & 10 & 103 & 99 & 101 \\
\hline
\end{tabular}

1 Filter-press-cake rates calculated on a wet basis.

2 Plant cane, 1950-52, B. 34104 at Central Cortada, Aguirre.

${ }^{3}$ Plant cane and 2 ratoons, 1950-54, P. O. J. 2878 at Lajas Substation.

4 First and second ratoons, 1950-52, P. R. 902 at Colonia Irurena, Isabela.

5 Plant cane and 2 ratoons, 1951-54, P. R. 905 at Corozal Substation.

${ }^{6}$ First and second ratoons, 1952-54, P. O. J. 2878 at Colonia Santa Teresa, Humacao.

fertilizer was used along with the filter-press cake in most of the experiments. It, therefore, seemed wasteful to apply any appreciable quantity of filter-press cake to a field to which commercial fertilizer had just been applied.

It is interesting to note that the filter-press cake not only failed to increase yields on unirrigated Santa Isabel silty clay, but actually decreased them with increasing rates of application of filter-press cake in the absence of inorganic fertilizers (see table 2).

Because large quantities of inorganic material are returned to the soil by the cane trash (7), much of the beneficial influence of filter-press cake is lost as a soil ammendment in controlling soil moisture, aeration, and temperature. The filter-press cake is beneficial to soils requiring nitrogen 
and phosphorus. However, where potash requirements are high, the use of filter-press cake only may not guarantee an adequate supply of potassium for the cane.

\section{VEGETABLE CROPS}

Filter-press cake has always found favor among our farmers in growing vegetables. Its widest usage has been for the home garden and small vegetable plots of usually less than 1 acre.

\section{Tomatoes}

As shown in table 3, filter-press cake increased the yields of tomatoes. When used alone, 20 tons of filter-press cake gave no significantly higher yields than did 10 tons per acre. No significant response in yield was obtained with the use of 10 or 20 tons of filter-press cake in conjunction with commercial fertilizer, as compared with commercial fertilizer alone (table 3 , treatments 5 and 6 compared with 4 ). There was a need for nitro-

TABLE 3.-Influence of filter-press cake and commercial fertilizers on yields of tomatoes and peppers

\begin{tabular}{|c|c|c|c|c|c|c|}
\hline \multirow{3}{*}{ Treatment No. } & \multicolumn{4}{|c|}{ Fertilizer treatments, per acre of- } & \multicolumn{2}{|c|}{ Yields of produce per acre } \\
\hline & \multicolumn{3}{|c|}{ Commercial inorganic fertilizer as- } & \multirow{2}{*}{$\begin{array}{c}\text { Filter-press } \\
\text { cake }^{1}\end{array}$} & \multirow{2}{*}{ Tomatoes ${ }^{2}$} & \multirow{2}{*}{ Peppers ${ }^{3}$} \\
\hline & $\mathbf{N}$ & $\mathrm{P}_{2} \mathrm{O}_{5}$ & $\mathrm{~K}_{2} \mathrm{O}$ & & & \\
\hline & Pounds & Pound & Pounds & Tons & Cwwt. & Cwot. \\
\hline 1 & 0 & 0 & 0 & 0 & 37.5 & 33.0 \\
\hline 2 & 0 & 0 & 0 & 10 & 68.6 & 57.0 \\
\hline 3 & 0 & 0 & 0 & 20 & 84.0 & 52.5 \\
\hline 4 & 100 & 200 & 200 & 0 & 136.4 & 48.6 \\
\hline 5 & 100 & 200 & 200 & 10 & 135.0 & 86.2 \\
\hline 6 & 100 & 200 & 200 & 20 & 158.9 & 77.9 \\
\hline 7 & 0 & 200 & 200 & 0 & 80.5 & 60.4 \\
\hline 8 & 200 & 0 & 200 & 0 & 84.7 & 30.0 \\
\hline 9 & 200 & 200 & 0 & 0 & 145.5 & 62.7 \\
\hline \multirow{2}{*}{\multicolumn{5}{|c|}{$\begin{array}{l}\text { Least significant difference needed between treatments at: } \\
\text { 5-percent level } \\
\text { 1-percent level }\end{array}$}} & 30.9 & 22.6 \\
\hline & & & & & 41.1 & 30.0 \\
\hline
\end{tabular}

- 1 Calculated on a wet basis.

2 Data taken from experiment conducted at the Isabela Substation, 1952-53, on a Coto clay with Plamar variety of tomato.

${ }^{3}$ Data taken from experiment conducted at Aibonito, 1952-53, on a Juncos clay with a Puerto Rico Wonder variety of pepper. 
gen (treatment 4 compared with 7), and for phosphorus (treatment 4 compared with 8 ), but not for potassium (treatment 4 compared with 9 ).

It is of interest to note that inorganic fertilizers alone gave greater yields of tomatoes than did filter-press cake only (treatment 4 compared with treatments 5 and 6 ). Riollano (6), working with tomatoes in the same soil, Coto clay, obtained a significant increase in yield by using 12 tons of filter-press cake, plus 1,000 pounds of 8-10-15 fertilizer.

\section{Peppers}

The use of filter-press cake at the rate of 10 tons per acre (table 3 , treatment 2 minus treatment 1), increased yields of peppers, but 20 tons did not as compared with 10 tons per acre. The use of 10 tons per acre of filter-press cake in combination with commercial fertilizer also increased yields above those obtained with the commercial fertilizer alone (treatment 5 less treatment 4). No greater yield increases were obtained when 20 tons of filter-press cake were used instead of 10 along with the inorganic fertilizer.

\section{Pigeon peas}

Filter-press cake was applied at a rate of 20 tons per acre to pigeon peas growing on a Coto clay at the Isabela Substation, 1953-54. The results of the harvests for 2 years showed no yield response, nor did yields respond to the use of various inorganic fertilizers containing nitrogen, phosphorus, or potassium. It appears that the pigeon pea was able to obtain sufficient available nutrient supply from the soil without fertilizer applications.

\section{Corn}

Mayorbela corn grown at the Lajas Substation on a Santa Isabel clay was fertilized with ammonium sulfate and also with filter-press cake in amounts equivalent to 120 pounds of $\mathrm{N}$ per acre. There was no significant response in yield to either.

\section{TOBACCO}

Filter-press cake was used as a fertilizer in a tobacco fertilizer experiment at Aibonito on a Juncos clay. The results obtained are given in table 4. When filter-press cake was applied as a nitrogen source using rates equivalent to the nitrogen applied in the form of ammonium sulfate (treatment 3 ), there was a significant increase over the no-nitrogen treatment (treatment 1). However, yield increases were significantly higher when ammonium sulfate was used as the nitrogen source (treatment 2 compared with treatment 3). When one-half of the nitrogen was in the form of 
TABLE 4.-Influence of filter-press cake and commercial fertilizers on yields of tobacco ${ }^{1}$

\begin{tabular}{|c|c|c|c|c|c|c|c|c|}
\hline \multirow{3}{*}{ Treatment No. } & \multicolumn{4}{|c|}{ Fertilizer treatment per acre of- } & \multicolumn{4}{|c|}{ Yield of tobacco per acre } \\
\hline & \multicolumn{3}{|c|}{$\begin{array}{c}\text { Commercial inorganic ferti- } \\
\text { lizer as- }\end{array}$} & \multirow{2}{*}{$\begin{array}{c}\text { Filter- } \\
\text { press }^{2} \\
\text { cake }^{2}\end{array}$} & \multirow{2}{*}{$\begin{array}{l}\text { First crop, } \\
1951-52\end{array}$} & \multirow{2}{*}{$\begin{array}{c}\text { Second } \\
\text { crop, } \\
1952-53\end{array}$} & \multirow{2}{*}{$\begin{array}{l}\text { Third crop, } \\
1953-54\end{array}$} & \multirow{2}{*}{$\begin{array}{l}\text { Mean of } \\
3 \text { crops }\end{array}$} \\
\hline & $\mathrm{N}$ & $\mathrm{P}_{2} \mathrm{O}_{6}$ & $\mathrm{~K}_{2} \mathrm{O}$ & & & & & \\
\hline & Pounds & Pounds & Pounds & Tons & Cwt. & Cwzt. & Cwt. & Cwi. \\
\hline 1 & 0 & 100 & 150 & 0 & 6.34 & 8.26 & 8.77 & 7.99 \\
\hline 2 & 100 & 100 & 150 & 0 & 12.38 & 10.50 & 20.60 & 14.49 \\
\hline 3 & 0 & 100 & 150 & $2.5^{3}$ & 9.55 & 10.52 & 14.01 & 11.36 \\
\hline 4 & 50 & 100 & 150 & $1.25^{4}$ & 11.57 & 8.61 & 17.51 & 13.20 \\
\hline 5 & 150 & 0 & 150 & 0 & 10.80 & 10.29 & 13.50 & 10.97 \\
\hline 6 & 150 & 100 & 0 & 0 & 12.43 & 10.00 & 18.33 & 13.68 \\
\hline 7 & 0 & 100 & $150^{5}$ & $2.5^{3}$ & 一 & 11.19 & 15.01 & 一 \\
\hline 8 & 100 & 100 & $150^{5}$ & 0 & - & & 23.90 & - \\
\hline \multirow{3}{*}{\multicolumn{5}{|c|}{$\begin{array}{l}\text { Least significant differences needed be- } \\
\text { tween treatments at: }\end{array}$}} & & & & \\
\hline & & & & & 2.17 & 1.31 & 3.29 & 2.26 \\
\hline & & & & & 2.81 & 1.71 & 4.34 & 2.95 \\
\hline
\end{tabular}

1 Virginia 12 variety of tobacco grown on a Juncos clay at Aibonito.

${ }^{2}$ Calculated on a dry-weight basis.

${ }^{3}$ The 2.5 tons of filter-press cake (2-percent $\mathrm{N}$ ) used was calculated to contain $100 \mathrm{lb}$. of $\mathrm{N}$.

${ }^{4}$ The 1.25 tons of filter-press cake (2-percent $\mathrm{N}$ ) used was calculated to contain $50 \mathrm{lb}$. of $\mathrm{N}$.

${ }^{5} \mathrm{Lime}$ was applied at the rate of 2 tons of $\mathrm{CaCO}_{3}$ per acre.

ammonium sulfate and one-half was derived from filter-press cake (treatment 4), the yields were comparable to those obtained when ammonium sulfate only was used. Inasmuch as tobacco is a short-growing crop requiring only a few months to attain maturity, it appears that the decomposition of filter-press cake is not sufficiently rapid in this soil to supply the crop's heavy immediate demand for nitrogen.

Phosphorus was also needed by tobacco, but no significant yield increases were obtained from potash applications.

The highest tobacco yields were obtained when lime was used with inorganic fertilizer (treatment 8). However, when filter-press cake was substituted to supply nitrogen equivalent to that supplied by ammonium sulfate, no such yield increase with the addition of lime was noted (treatment 7).

At present no explanation can be offered for this failure of increasing yields significantly when lime is used in conjunction with filter-press cake. 
TABLE 5.-Influence of filter-press cake and commercial fertilizer on the yields of root crops

\begin{tabular}{|c|c|c|c|c|c|c|c|}
\hline \multirow{3}{*}{$\begin{array}{l}\text { Treatment } \\
\text { No. }\end{array}$} & \multicolumn{4}{|c|}{ Fertilizer treatment per acre of- } & \multicolumn{3}{|c|}{ Yield of root crops per acre } \\
\hline & \multicolumn{3}{|c|}{ Commercial inorganic fertilizer as- } & \multirow{2}{*}{$\begin{array}{c}\text { Filter-press } \\
\text { cake }^{1}\end{array}$} & \multirow{2}{*}{ Yams ${ }^{2}$} & \multirow{2}{*}{$\begin{array}{c}\text { Sweet- } \\
\text { potatoes }^{3}\end{array}$} & \multirow{2}{*}{$\begin{array}{c}\text { Yautías } \\
\text { (dasheen) }\end{array}$} \\
\hline & $\mathrm{N}$ & $\mathrm{P}_{2} \mathrm{O}_{6}$ & $\mathrm{~K}_{2} \mathrm{O}$ & & & & \\
\hline & Pounds & Pounds & Pounds & Tons & $C w t$. & Cwt. & Cwt. \\
\hline 1 & $\mathbf{0}$ & 0 & 0 & 0 & 231 & - & 一 \\
\hline 2 & 225 & 100 & 225 & 0 & 249 & 一 & 一 \\
\hline 3 & 225 & 100 & 225 & 15 & 239 & 一 & 一 \\
\hline 4 & 0 & 0 & 0 & 10 & - & 29 & 33 \\
\hline 5 & 0 & 0 & 0 & 20 & - & 31 & 53 \\
\hline 6 & 183 & 200 & 200 & 0 & 一 & 47 & - \\
\hline 7 & 83 & 100 & 100 & 10 & - & 57 & - \\
\hline 8 & 100 & 200 & 200 & 0 & - & - & 19 \\
\hline 9 & 100 & 200 & 200 & 10 & - & - & 51 \\
\hline 10 & 100 & 200 & 200 & 20 & - & - & 53 \\
\hline \multirow{3}{*}{\multicolumn{5}{|c|}{$\begin{array}{l}\text { Least significant differences needed between } \\
\text { treatments at: }\end{array}$}} & & & \\
\hline & & & & & 38 & 14 & 18 \\
\hline & & & & & - & 19 & 23 \\
\hline
\end{tabular}

1 Calculated on a wet basis.

2 White Guinea yam, (Dioscorea rotundata), grown at Utuado on a Lares clay, 1951-52.

${ }^{3}$ U.P.R. 3, yellow-fleshed sweetpotato grown at Loíza on a Cataño loamy sand, 1950.

${ }^{4}$ Kelly yautía (Xanthosoma atrovirens), grown at the Corozal Substation on a Lares clay, 1953.

ROOT CROPS

\section{Yams}

The White Guinea variety of yam, Dioscorea rotundata, was grown on a Lares clay at Utuado with applications of filter-press cake. The results in table 5 show no significant yield response to either filter-press cake or mixed fertilizer.

\section{Sweetpotatoes}

Filter-press cake failed to increase sweetpotato yields on a Cataño loamy sand when used alone or in conjunction with a mixed fertilizer. The use of 10 tons of filter-press cake per acre, plus a mixed fertilizer (table 5, treatment 7), gave no significantly increased yields over those obtained 
with mixed fertilizers alone (treatment 6). Yield increases were not marked when filter-press cake was used alone (treatments 4 and 5). This soil responded to potash fertilizers. Filter-press cake lacked sufficient potash to produce high sweetpotato yields when used alone, but high yields were realized when it was combined with inorganic fertilizers to supply extra potash. Sweetpotatoes have a high demand for potash (2); if filter-press cake is to be used as a fertilizer for this crop it must be reenforced with additional potash.

\section{Yautías}

Yautías, Xanthosoma atrovirens, Kelly variety, were fertilized with filterpress cake on the heavy Lares clay at Corozal. The use of it alone, or in combination with inorganic fertilizers, increased yields significantly as compared with the use of inorganic fertilizers only (table 5). Filter-press cake gave higher yields at 20 than at 10 tons per acre, when used alone. In combination with inorganic mixed fertilizer, 20 tons per acre of filterpress cake proved to be no better than 10 . The yautias did not respond to potash applications in this experiment.

\section{PLANTAINS}

Filter-press cake did not prove beneficial to plantains grown at the Corozal Substation on a Lares Clay, 1950-51. The use of 10 tons of filterpress cake, plus 2,000 pounds of a 10-10-10 commercial fertilizer per acre, gave no increase in yield over that obtained with the use of 2,000 pounds of the 10-10-10 fertilizer alone. The soil received an application of 7,500 pounds of lime $\left(\mathrm{CaCO}_{3}\right)$ per acre. Yields were reduced from 22 pounds of plantains per tree with commercial fertilizer to 16 pounds with fertilizer plus filter-press cake.

\section{PINEAPPLES}

The influence of filter-press cake on pineapple yields must be re-evaluated in light of our newly acquired knowledge of the limiting factors imposed by biological-parasitic factors on pineapple growth. Experiments conducted before adequate measures were taken to control soil nematodes, mealybugs, and other biological-parasitic factors produced variable results. Hernández-Medina, et al. (1) found that on a Bayamón silty clay at Manatí, 1951-53, the use of 20 tons of filter-press cake per acre, plus, 2,500 pounds of a 12-6-8 mixed fertilizer, gave no increase in yields over the mixed fertilizer used alone. On a Bayamón silty clay at Palo Blanco, Arecibo, 1950-51, there were no significant yield increases when up to 32 tons of filter-press cake per acre were applied without mixed fertilizers (1). However, the use of 32 tons of filter-press cake, plus 1,500 pounds of a 12-6-10 
formula, gave yields just as good as those obtained with 3,000 pounds per acre of a 12-6-10 fertilizer. A combination of 30 tons of filter-press cake and 3,000 pounds of a 12-6-10 formula was needed to produce the highest yields on a heavy Lares clay. Filter-press cake alone was insufficient.

When the soil and pineapple plants were properly treated with fumigants and insecticides to control biological-parasitic factors, filter-press cake at the rate of 20 tons per acre failed to increase yields on a Bayamón silty clay.

\section{DISCUSSION}

Filter-press cake has value as a fertilizer. However, as it is not concentrated, much more of it must be used than of inorganic mixed commercial fertilizers. But its nutrient concentration is sufficient to allow it to compete with organic fertilizer sources such as animal manures, In table 6 a comparison is made of the fertilizer composition of filter-press cake and regularly used organic fertilizer' materials. Except for its lower potash content, filter-press cake's fertilizer value is greater than that of animal manures, but it does not have as good a composition as the seed meals and animal tankages. Because of high shipping rates on imports of the bulky organic fertilizer materials, filter-press cake can be used to replace these at quite a saving in transportation costs.

When applied directly from the factory to field or garden, filter-press cake will "burn" the plants like fresh animal manure. This so-called "burning" really results from the rapid decomposition of the new filter-press

TABLE 6.-A comparison of the chemical composition of filter-press cake, manures, and other organic-fertilizer sources ${ }^{1}$

\begin{tabular}{l|c|c|c}
\hline \multirow{2}{*}{ Fertilizer material } & \multicolumn{2}{|c}{ Composition on a dry-weight basis as- } \\
\cline { 2 - 4 } & $\mathrm{N}$ & $\mathrm{P}_{2} \mathrm{O}_{5}$ & $\mathrm{~K}_{2} \mathrm{O}$ \\
\hline & Percent & Pounds & Percent \\
Filter-press cake & 2.2 & 2.8 & 0.5 \\
Cattle manure, shredded & 2.0 & 1.8 & 2.2 \\
Sheep or goat manure & 1.4 & 1.0 & 3.0 \\
Castor pomace & $4.1-6.6$ & $1-2$ & $1-1.5$ \\
Cottonseed meal & $6.7-7.4$ & $2-3$ & $1.5-2$ \\
Fish tankage & $6.5-10$ & $4-8$ & - \\
Garbage tankage & $2.5-3.3$ & $2-5$ & $.5-1$ \\
Sewage sludge (activated) & $4.1-6.4$ & $2.5-4$ & - \\
Tankage (animal) & $5-10$ & $3-13$ & - \\
Tobacco stems & $1.2-3.3$ & - & $4-9$ \\
\hline
\end{tabular}

${ }^{1}$ Chemical composition of the manures and other organic-fertilizer sources adopted from (4). 
cake which liberates heat and ammonia and other nutrients in high concentrations. Many farmers allow filter-press cake to "cure", or to complete its initial decomposition, from 6 months to 1 year before using. However, this curing is not necessary for use on field crops if the fresh filter-press cake is applied sufficiently (about 6 weeks) in advance of planting. It will then have had time to complete its initial decomposition and will prove equal to well-rotted filter-press cake.

Filter-press cake has very little residual action on the soil. It decomposes quite rapidly, releasing the bulk of its nitrogen as nitrates. The peak of nitrate formation occurs in about 5 months after it is applied to the soil (see fig. 1). The low residual action of filter-press cake was shown very clearly in Ramírez's work (5) where different quantities up to 75 tons per acre produced appreciable yield increases in the plant cane, but failed to do so for the first ratoon crop, and proved less beneficial still to the second ratoon crop.

The authors personally have seen applications of filter-press cake as high as 200 tons or more per acre on a sandy soil fail to produce any influence 1 year thereafter. Unlike lime, filter-press cake does not produce a strong residual effect over a long period of time. The maximum organic matter a soil will contain under natural conditions is controlled by certain natural laws governing the soil and climate; the addition of amounts over this maximum will be wasteful in that the material added will be rapidly de-

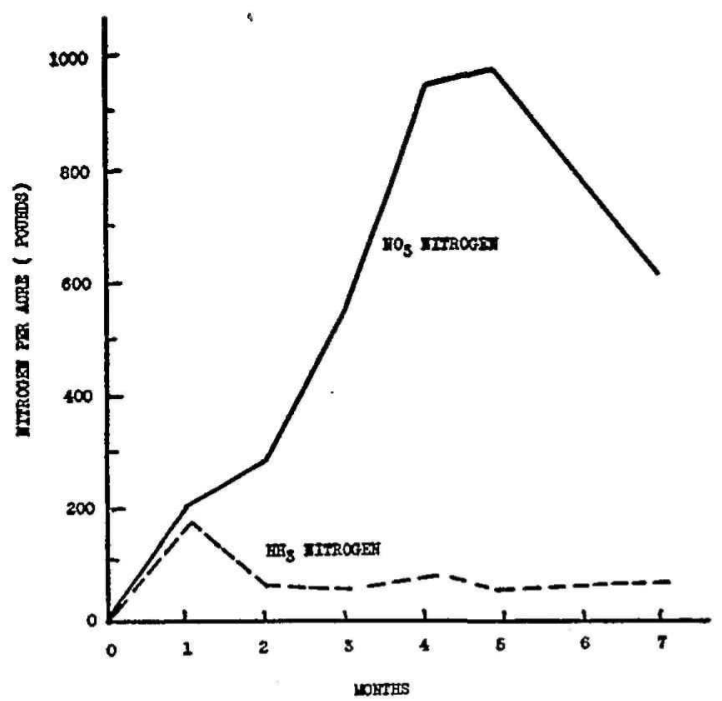

Frg. 1. -Nitrate $\left(\mathrm{NO}_{3}\right)$ and ammonia $\left(\mathrm{NH}_{3}\right)$ nitrogen produced per acre over a 7 -month period when 15 tons of filter-press cake per acre were added to a soil (after Ramírez (5)). 
stroyed by the soil microflora until the natural level is reached. Therefore, unnaturally high organic levels cannot be maintained in the soil by using filter-press cake.

When filter-press cake is available from a nearby local source, its main cost is that of transportation and application. Because of its great bulk, these costs may be high for large applications. Fresh filter-press cake contains about 60 percent of moisture by weight and even when piled at the factory and allowed to stand, the moisture runs from 15 to 45 percent. Because of its high moisture content and variations caused by place and method of storage, filter-press cake applications will vary greatly in their nutrient content.

For example, a truck of 5 cubic yards capacity can haul about 2.3 tons per load of fresh filter-press cake containing 60 -percent moisture by weight. This represents about 40 pounds of $\mathrm{N}, 50$ of $\mathrm{P}_{2} \mathrm{O}_{5}$, and 8 of $\mathrm{K}_{2} \mathrm{O}$ per acre. An application of 15 tons of filter-press cake (61/2 truckloads) to an acre of cane land would mean that the cane would receive in fertilizer material equivalents of about 250 pounds of $\mathrm{N}, 325$ of $\mathrm{P}_{2} \mathrm{O}_{5}$, and 50 of $\mathrm{K}_{2} \mathrm{O}$. Filterpress cake of 30-percent moisture content weighs about 1.9 tons per 5 cubic yards and it would require 8 truckloads to deliver 15 tons to a field. But now more nutrients and less water are present, so that 1 acre of cane receiving

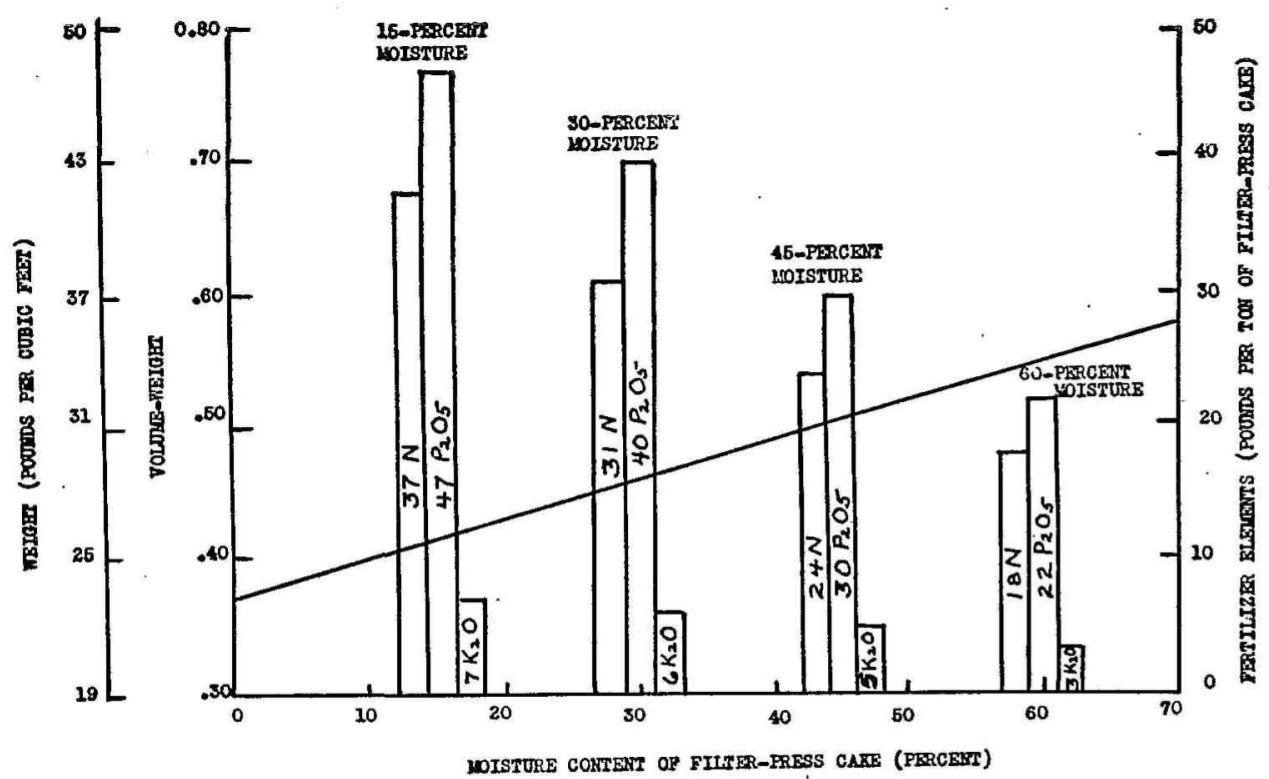

FIG. 2.-Volume-weight and nutrient content $\left(\mathrm{N}-\mathrm{P}_{2} \mathrm{O}_{5}-\mathrm{K}_{2} \mathrm{O}\right)$ of filter-press cake at various moisture contents. 
the 15 tons of 30 -percent-moisture filter-press cake would get about 450 pounds of $\mathrm{N}, 600$ of $\mathrm{P}_{2} \mathrm{O}_{5}$, and 100 of $\mathrm{K}_{2} \mathrm{O}$.

To facilitate calculations of the volume or weight of filter-press cake at various moisture contents, figure 2 has been constructed from experimental measurements. The $\mathrm{N}, \mathrm{P}_{2} \mathrm{O}_{5}$, and $\mathrm{K}_{2} \mathrm{O}$ contained in 1 ton of filter-press cake at certain moisture contents are also presented therein as a guide to the use of this material.

In any discussion of filter-press cake it should be mentioned that it is a perfect medium for breeding insects. To kill flies, ants, and other insects usually present when filter-press cake is being handled, spray it with chlordane or aldrin. This does not interfere with its fertilizing properties at all.

\section{SUMMARY}

This study on the use of filter-press cake as a fertilizer material may be summarized as follows:

1. It is a byproduct of the sugarcane mills consisting principally of a mixture of cane fibers, sucrose, coagulated colloids including cane wax, albumoids, and phosphates of lime, plus sand and soil.

2. It is a soft, spongy, lightweight, amorphous dark-brown to black material. When fresh from the filter-presses it contains about 60 percent of moisture, and about 15 percent when air-dry.

3. Its chemical composition averages 2.19 percent of $\mathrm{N}, 2.77$ percent of $\mathrm{P}_{2} \mathrm{O}_{5}, 0.44$ percent of $\mathrm{K}_{2} \mathrm{O}$, and 3.05 percent of $\mathrm{CaO}$, plus considerable quantities of the minor elements.

4. It did not produce appreciable yield increases when used on sugarcane in combination with commercial mixed inorganic fertilizer.

5. It was beneficial to tomatoes growing on a Coto clay when used at a rate of 10 tons per acre, but yields were higher when commercial fertilizer was used.

6. Ten tons per acre significantly increased yields of peppers on a Juncos clay.

7. Pigeon peas and corn responded to neither filter-press cake nor regular fertilizers.

8. Tobaceo yielded more when filter-press cake was used as a nitrogen source, but ammonium sulfate produced higher yields still when used to supply equivalent amounts of $\mathrm{N}$.

9. Yams did not respond to the use of filter-press cake.

10. Filter-press cake alone did not produce as good results on sweetpotatoes as commercial fertilizer.

11. Filter-press cake increased the yield of yautías.

12. Plantains did not respond to filter-press cake when grown on a Lares clay. 
13. Pineapples gave a mixed response to applications of filter-press cake. When damage caused by biological-parasitic factors was properly controlled, the filter-press cake applications did not increase yields.

14. The composition of filter-press cake, as compared with that of other organic fertilizers showed it to be about equal (except for low $\mathrm{K}_{2} \mathrm{O}$ ) to animal manures but not to animal tankage or seed meals.

15. If applied about 6 weeks prior to planting, the decomposition of fresh filter-press cake will not produce "burning" on vegetable crops.

\section{PRACTICAL RECOMMENDATIONS}

Filter-press cake may be used advantageously as a fertilizer material if adequate attention is paid to its limitations and full use is made of its particular advantages. Its main disadvantages are its low $\mathrm{K}_{2} \mathrm{O}$ content and large bulk combined with low concentrations of nutrients. Its main advantages are its cheapness, slower release of nutrients, minor-element content, high water-holding capacity, high exchange capacity, and mulching properties.

The following recommendations are made for its use on crops:

1. Apply yearly in small amounts rather than in very large applications once in 3 to 4 years.

2. Use more on light-textured soils, than on heavy clays.

3. Use carefully on very poorly drained soils, not applying the filter-press cake too deeply in the soil, which prevents proper decomposition.

4. Large applications must undergo thorough incorporation into the plowed layer. Surface application and incorporation with the upper inch or two of soil is better for small applications. For root crops, application in the hole below the seed makes better use of minimum quantities.

5. Filter-press cake should be applied to fast-growing crops such as vegetables and tobacco a few weeks before planting, especially if the filter-press cake is not well rotted.

6. Filter-press cake should be supplemented with potash fertilizer when used for crops or soils with high potash demands, about 30 pounds of $\mathrm{KCl}$ for every ton of fresh filter-press cake containing 60 percent of moisture.

7. The maximum yearly recommendations in tons per acre for specific crops are: Sugarcane 10, pineapple 30, root crops 20, ornamentals 10 to 20 , coffee 20 , tobacco 10 , vegetables 10 , and plantains 10 .

\section{RESUMEN}

Este estudio sobre el uso de la cachaza como materia fertilizante puede resumirse como sigue:

1. La cachaza es un producto secundario resultante de la elaboración del azúcar en las centrales azucareras, el cual consiste de una mezcla de fibra, 
sacarosa, coloides coagulados incluyendo la cera de la caña, albuminoides, fosfatos de cal, y arena y tierra.

2. Es una materia amorfa, de color marrón obscuro a negro, blanda, esponjosa y liviana.

3. Su composición química tiene el porcentaje promedio siguiente: 2.19 de $\mathrm{N} ; 2.77$ de $\mathrm{P}_{2} \mathrm{O}_{5} ; 0.44$ de $\mathrm{K}_{2} \mathrm{O} ; 3.05$ de calcio y cantidades considerables de elementos menores.

4. Cuando se usa en combinación con los fertilizantes comerciales mezclados, no produce aumentos apreciables al aplicarse a la caña de azúcar.

5. Es muy beneficiosa para el tomate que se siembra en arcilla Coto, si se aplica a razón de 10 toneladas por acre, aunque se ha conseguido aumentar los rendimientos cuando se combinó con abonos comerciales.

6. En arcilla Juncos se logró aumentar significativamente los rendimientos del pimiento cuando se usó a razón de 10 toneladas por cuerda.

7. El gandul y el maíz no respondieron a las aplicaciones de cachaza ni a los abonos comerciales.

8. El tabaco rindió más cuando se le aplicó cachaza como fuente principal de nitrógeno, pero el sulfato amónico ejerció mejor efecto, en cuanto a aumentar los rendimientos, cuando se usó para suplir cantidades equivalentes de nitrógeno.

9. El ñame no respondió a las aplicaciones de cachaza.

10. La cachaza sola, aplicada a la batata, no produjo tan buenos resultados como cuando se le aplicó abono comercial a esta cosecha.

11. La cachaza aumentó los rendimientos de la yautía.

12. El plátano no respondió a las aplicaciones de cachaza en la arcilla de Lares.

13. La piña no respondió en forma conclusiva a las aplicaciones de cachaza. Se observó que cuando el daño a las plantas, causado por factores bioparasíticos, fué debidamente controlado, las aplicaciones de cachaza no aumentaron los rendimientos.

14. Al compararse la composición química de la cachaza con la de otras materias orgánicas fertilizantes se encontró que era casi igual (exceptuando su menor cantidad de $\mathrm{K}_{2} \mathrm{O}$ ) que los estiércoles de origen animal, pero diferente al tancaje animal y a las harinas de semillas.

15. Aplicándose al terreno seis semanas antes de la siembra, se encontró que la cachaza fresca no quemó las plantas recien sembradas.

\section{RECOMENDACIONES PRACTICAS}

La cachaza puede usarse remunerativamente como materia fertilizante si se presta adecuada atención a sus limitaciones, a la vez que se aprovechan sus peculiares ventajas. Está limitada por un contenido bajo de $\mathrm{K}_{2} \mathrm{O}$, y su volumen es relativamente enorme si se considera las concentraciones bajas 